\title{
In silico identification of a multi-functional regulatory protein involved in Holliday junction resolution in bacteria
}

\author{
Yan Zhang ${ }^{1 *}$, Jie Lin', Yang Gao² \\ From The 5th IEEE International Conference on Computational Systems Biology (ISB 2011) \\ Zhuhai, China. 02-04 September 2011
}

\begin{abstract}
Background: Homologous recombination is a fundamental cellular process that is most widely used by cells to rearrange genes and accurately repair DNA double-strand breaks. It may result in the formation of a critical intermediate named Holliday junction, which is a four-way DNA junction and needs to be resolved to allow chromosome segregation. Different Holliday junction resolution systems and enzymes have been characterized from all three domains of life. In bacteria, the RuvABC complex is the most important resolution system.

Results: In this study, we conducted comparative genomics studies to identify a novel DNA-binding protein, YebC, which may serve as a key transcriptional regulator that mainly regulates the gene expression of RuvABC resolvasome in bacteria. On the other hand, the presence of YebC orthologs in some organisms lacking RuvC implied that it might participate in other biological processes. Further phylogenetic analysis of YebC protein sequences revealed two functionally different subtypes: YebC_I and YebC_II. Distribution of YebC_I is much wider than YebC_II. Only YebC_I proteins may play an important role in regulating RuvABC gene expression in bacteria. Investigation of YebC-like proteins in eukaryotes suggested that they may have originated from YebC_II proteins and evolved a new function as a specific translational activator in mitochondria. Finally, additional phylum-specific genes associated with Holliday junction resolution were predicted.
\end{abstract}

Conclusions: Overall, our data provide new insights into the basic mechanism of Holliday junction resolution and homologous recombination in bacteria.

\section{Background}

Homologous recombination is a fundamental mechanism in biology that rearranges genes within and between chromosomes, promotes DNA repair, and guides segregation of chromosomes at division. This process is common to all forms of life and involves the exchange (i.e., breakage and reunion) of DNA sequences between two chromosomes or DNA molecules [1-4]. Such exchange provides a valid evolutionary force that contributes to promote genetic diversity and to conserve genetic identity. In addition, homologous recombination is also used

\footnotetext{
* Correspondence: yanzhang01@sibs.ac.cn

'Key Laboratory of Systems Biology, Shanghai Institutes for Biological

Sciences, Chinese Academy of Sciences, Shanghai, 200031 China

Full list of author information is available at the end of the article
}

in horizontal gene transfer to exchange genetic material between different strains and species of bacteria and viruses [5].

Although homologous recombination varies widely among different organisms and cell types, most forms of it involve the same basic steps: (i) after a DNA break occurs, sections of DNA around the break on the 5 ' end of the damaged chromosome are removed in a process called resection; (ii) in the strand invasion step that follows, an overhanging 3' end of the damaged chromosome then "invades" an undamaged homologous chromosome; (iii) after strand invasion, one or two cross-shaped structures (called Holliday junctions) are formed to connect the two chromosomes. Holliday junction (or four-way junction) has been generally assumed 
as a key intermediate in genetic recombination and DNA repair since its discovery in 1964 [6]. They are highly conserved structures from prokaryotes to mammals, which adjoin two DNA duplexes, forming a branch point where four helices are interconnected by strand exchange $[7,8]$.

Because Holliday junctions provide a covalent linkage between chromosomes, their efficient resolution is essential for proper chromosome segregation. Enzymes that resolve Holliday junctions by endonucleolytic cleavage have been isolated from bacteriophages, bacteria, archaea and certain eukaryotes [9-12]. In Escherichia coli, the enzymes that are involved in resolution of Holliday junction include RuvABC, RecU, RecG, and RusA [13-15]. The RuvABC proteins (or RuvABC resolvasome) constitute a simple and the most widely used system for the processing of Holliday junctions. RuvAB proteins catalyze the branch migration whereas RuvC endonuclease resolves the Holliday junction into duplex products $[15,16]$. RecU, a RuvC functional analog, was found to serve as a Holliday junction resolvase in some firmicutes and mollicutes that lack RuvC $[17,18]$. The RecG protein is a DNA helicase and may promote branch migration of a variety of branched DNAs including Holliday junctions $[19,20]$. The RusA protein is a homodimeric Holliday junction-specific endonuclease and can bind a variety of branched DNA structures $[21,22]$. RecG may be required by RusA to branch migrate Holliday junctions to cleavable sequences [9].

Homologs of RuvABC, RecU, RecG, and RusA are absent from almost all sequenced archaea and eukaryotes. In archaea, the Hjc protein, a distantly related member of the type II restriction endonuclease family, has been characterized to serve as a Holliday junction resolving enzyme $[23,24]$. Little is known about the mechanism of eukaryotic Holliday junction resolution and the enzymes involved. It was reported that Saccharomyces cerevisiae contains a Holliday junction resolvase Cce1 [25,26], an equivalent enzyme from Schizosaccharomyces pombe (named Ydc2) has also been found [27]. These enzymes are targeted to the mitochondria, suggesting that they can only cleave junctions formed during recombination of mitochondrial DNA. Very recently, a nuclear Holliday junction resolvase was first identified from both humans and yeast [28]. These resolvases (GEN1 in human and its yeast ortholog Yen1) represent a new subclass of the the Rad2/XPG family of nucleases, and promote Holliday junction resolution in a manner similar to that shown by the E. coli RuvC $[29,30]$. However, the precise mechanism regulating the activities of these enzymes is unknown and the factors involved remain unidentified.

In this study, we carried out comparative genomics approaches to investigate the mechanisms of Holliday junction resolution in prokaryotes. Occurrence of known components of Holliday junction resolution (e.g., RuvABC and RecU) could be easily identified by comparative genomics. Our analysis also generated evidence for a novel DNA-binding regulatory protein family involved in Holliday junction resolution in bacteria. Homologs of this family were detected in a variety of eukaryotes and are predicted to be localized in mitochondria. Overall, these data provide new insight for better understanding the basic mechanism of homologous recombination in nature.

\section{Results and discussion}

\section{Distribution of the RuvABC/RecU Holliday junction resolution system in prokaryotes}

Except a very small number of organisms (less than 2\%) with small and condensed genomes (mostly parasites), all sequenced bacteria contain RuvA and RuvB genes. As RuvAB complex may catalyze both Holliday junction branch migration and replication fork reversal [31,32], the occurrence of their genes may not precisely reflect the Holliday junction resolution trait. Thus, we used the co-occurrence of RuvABC or RuvAB/RecU as a signature for the presence of RuvABC/RecU-dependent Holliday junction resolution trait.

Sequence analysis of bacterial genomes revealed a wide distribution of RuvABC resolvasome. We identified 1240 organisms ( $80 \%$ of all sequenced bacteria) that contain this system, which is consistent with previous observations that RuvABC complex is the most important Holliday junction resolution system in bacteria $[9,33]$. Details are shown in Table S1 [see additional file 1]. All RuvC-containing organisms have RuvA and RuvB, most of which have RuvABC genes within the same operon. The RuvAB/RecU system was detected in 256 organisms (255 in Firmicutes and Mollicutes), almost all of which lack RuvC genes. All detected RecU genes are distant from RuvAB genes based on genomic context analysis. Among all examined genomes, only four organisms belonging to Firmicutes/Clostridia were found to have both RuvC and RecU genes. Figure 1 shows the distribution of RuvABC and RuvAB/RecU systems in different bacterial taxa based on a highly resolved phylogenetic tree of life developed by Ciccarelli and coworkers [34]. Our data are consistent with previous studies that RuvC was replaced by its functional analog $\operatorname{Rec} U$ in firmicutes and mollicutes $[17,18]$. On the other hand, the absence of both resolvase genes in 27 organisms that have RuvAB complex might suggest the presence of unknown resolvase or alternative resolution system (such as RecG-RusA) in these organisms. In contrast to bacteria, only two closely related archaea in Methanomicrobiales (Methanoregula boonei and Methanospirillum hungatei) were found to have RuvABC system, suggesting that they recently acquired 


\begin{tabular}{|c|c|c|c|c|c|c|c|}
\hline & & Bacterial phyla & Organisms & RuvABC & $\begin{array}{l}\text { RuvAB } \\
\text { IRecU }\end{array}$ & YebC & $\begin{array}{c}\text { YebC-RuvC } \\
\text { operon }\end{array}$ \\
\hline & & Tenericutes/Mollicutes & 30 & - & 26 & 24 & - \\
\hline & & Firmicutes/Others & 36 & 21 & 15 & 36 & 17 \\
\hline & & Firmicutes/Lactobacillales & 99 & - & 99 & 99 & - \\
\hline & & Firmicutes/Bacillales & 71 & 12 & 58 & 70 & 2 \\
\hline & & Firmicutes/Clostridia & 150 & 83 & 57 & 147 & 34 \\
\hline & & Synergistetes & 7 & 7 & - & 7 & 7 \\
\hline & & Deferribacteres & 3 & 3 & - & 3 & 3 \\
\hline & & Nitrospirae & 2 & 1 & - & 2 & - \\
\hline & & Chlamydiae & 11 & 11 & - & 11 & - \\
\hline & & Bacteroidetes & 107 & 103 & 1 & 105 & 3 \\
\hline & & Chlorobi & 11 & 11 & - & 11 & 11 \\
\hline & & Actinobacteria & 160 & 160 & - & 160 & 139 \\
\hline & & Spirochaetes & 34 & 25 & - & 34 & 19 \\
\hline & & Planctomycetes & 8 & 8 & - & 8 & - \\
\hline & & Cyanobacteria & 45 & 45 & - & 45 & $\cdot$ \\
\hline & & Chloroflexi & 17 & 17 & - & 17 & 14 \\
\hline & & Deinococcus-Thermus & 13 & 13 & - & 13 & 2 \\
\hline & & Thermotogae & 12 & 12 & - & 12 & - \\
\hline & & Aquificae & 10 & 3 & - & 10 & 3 \\
\hline & & Dictyoglomi & 2 & 2 & - & 2 & 2 \\
\hline & & Elusimicrobia & 1 & 1 & - & 1 & 1 \\
\hline & & Candidate division TG1 & 1 & 1 & - & 1 & 1 \\
\hline & & Fusobacteria & 21 & 21 & - & 21 & - \\
\hline & & Lentisphaerae & 2 & 2 & - & 2 & 1 \\
\hline & & Verrucomicrobia & 9 & 9 & - & 9 & - \\
\hline & & Candidate division TM7 & 3 & 1 & - & 2 & - \\
\hline & & Acidobacteria & 6 & 6 & - & 6 & 1 \\
\hline ப & & Deltaproteobacteria & 47 & 46 & - & 47 & 36 \\
\hline & & Epsilonproteobacteria & 36 & 36 & - & 36 & - \\
\hline & & Alphaproteobacteria/Rickettsiales & 32 & 29 & - & 31 & 1 \\
\hline & & Alphaproteobacteria/Others & 151 & 149 & - & 149 & 58 \\
\hline & & Alphaproteobacteria/Rhizobiaceae & 11 & 11 & - & 11 & 9 \\
\hline & & Betaproteobacteria/Bordetella & 5 & 5 & - & 5 & - \\
\hline & & Betaproteobacteria/Burkholderiaceae & 35 & 35 & - & 35 & - \\
\hline & & Betaproteobacteria/Neisseriaceae & 21 & 21 & - & 21 & - \\
\hline & & Betaproteobacteria/Others & 59 & 57 & - & 57 & 18 \\
\hline & & Gammaproteobacteria/Enterobacteriales & 79 & 74 & - & 74 & 71 \\
\hline & & Gammaproteobacteria/Pasteurellaceae & 18 & 18 & - & 18 & 18 \\
\hline & & Gammaproteobacteria/Vibrionaceae & 29 & 29 & - & 29 & 11 \\
\hline & $t^{L}$ & Gammaproteobacteria/Pseudomonadaceae & ae 17 & 17 & - & 17 & 17 \\
\hline & & Gammaproteobacteria/Xanthomonadaceae & ae 12 & 12 & - & 12 & 12 \\
\hline & & Gammaproteobacteria/Others & 124 & 121 & - & 122 & 66 \\
\hline & & Proteobacteria/Others & 2 & 2 & - & 2 & 1 \\
\hline & & Total & 1549 & 1240 & 256 & 1524 & 578 \\
\hline
\end{tabular}

this system from bacteria by horizontal gene transfer. No RecU homolog could be detected in archaea.

\section{Identification of a new family involved in RuvABC-} dependent Holliday junction resolution in bacteria Since the RuvABC complex has been shown to be the most widely used system for the resolution of Holliday junctions in bacteria, identification of functional linkages involving RuvABC (especially RuvC which is specific for Holliday junction resolution trait) may help understand the details of this important process. First, we used STRING web server [35] to examine possible functional linkages based on neighborhood, gene fusion and cooccurrence analyses. The top candidates for RuvA, RuvB 
or RuvC are shown in Table 1. Except for known components of RuvABC, the protein hit with the best score was $\mathrm{YebC}$, a putative cytoplasmic protein with unassigned function (COG0217, uncharacterized conserved protein; pfam01709, domain of unknown function DUF28). This gene was located very close to or even within the same operon with RuvC in many bacteria. In addition, YebC and RuvABC showed similar patterns of occurrence in most bacterial phyla based on the STRING output. The next predicted RuvABC link was YbgC, a bacterial 4-hydroxybenzoyl-CoA thioesterase involved in phospholipid metabolism and is also associated with the Tol-Pal system [36]. Most of other candidates predicted by STRING are also involved in TolPal system. It has been known that this system is important for cell envelope integrity and is part of the cell division machinery. In E. coli, the Tol-Pal system is composed of the YbgC, TolQ, TolA, TolR, TolB, Pal and $\mathrm{YbgF}$ proteins [36,37]. So far it is unclear whether some of these proteins are involved in DNA repair and recombination. Similar analysis was also done for $\operatorname{Rec} U$ and no strong functional partners could be assigned (data not shown). In this study, we only focus on YebC proteins.

Considering that $\mathrm{YebC}$ might be functionally associated with RuvABC resolvasome, we further analyzed the distribution of this protein family in all sequenced prokaryotes. Homologs of YebC were not detected in archaea, implying that YebC may either have evolved in bacteria or lost in the ancestors of archaea. In bacteria, the distribution of YebC appeared to be wider than RuvABC system (Figure 1). Almost all sequenced organisms (98\%) possess YebC genes, suggesting that YebC may be also involved in other processes independent of RuvABC system. However, the facts that all RuvC-containing organisms have $\mathrm{YebC}$, and that $\mathrm{YebC}$ and RuvC genes are located in the same operon in approximately half of the RuvC-containing organisms (Figure 1),

Table $\mathbf{1}$ STRING analysis of genes functionally associated
with RuvABC resolvasome.
\begin{tabular}{llll}
\hline Rank & RuvA & RuvB & RuvC \\
\hline 1 & RuvB & RuvA & RuvB \\
2 & RuvC & RuvC & RuvA \\
3 & YebC & YebC & YebC \\
4 & YbgC & QueA & YbgC \\
5 & TolB & YbgC & YeeN \\
6 & QueA & TolB & TolB \\
7 & FolC & PanB & CysS \\
8 & MaeB & TolQ & TolQ \\
9 & YeeN & TolR & QueA \\
10 & TolQ & YjeS & PurH \\
\hline
\end{tabular}

indicate a strong relationship between them. These results were consistent with a previous study of some "hypothetical" genes expressed in Haemophilus influen$z a e$, which also suggested a potential association of YebC with RuvABC in this organism [38].

\section{Phylogeny and functional classification of YebC family}

The majority of YebC-containing bacteria (92\%) have single copy of this gene. Intriguingly, in the organisms that have more than one YebC homologs, there is always one protein whose gene is located very close to either RuvC or RuvAB (when RuvC is absent) genes, implying that YebC proteins could be divided into different subgroups. Phylogenetic analysis of YebC proteins from sequenced bacteria revealed that $\mathrm{YebC}$ family may contain two subtypes: YebC_I and YebC_II (Figure 2).

Further analysis of bacterial genomes revealed wide but unbalanced distribution of different YebC subfamilies (Figure 3). YebC_I was present in nearly all bacterial phyla with the exception of Mollicutes, whereas YebC_II was detected in approximately half of the examined phyla (mostly in Bacteroidetes, Firmicutes and Proteobacteria). This observation suggests that YebC_I proteins may be used by most bacterial lineages and should be involved in an ancient trait that was common to all or almost all species in this domain of life. Interestingly, only members of YebC_I subgroup were found to be located very close to the genes encoding RuvC (Figure 3), implying a strong association between YebC_I and RuvC. In some of the organisms that lack RuvC (no matter whether they have RecU genes or not), YebC_I was located next to RuvAB genes, suggesting a potential link between YebC_I and RuvAB complex in the absence of RuvC in these organisms. However, it is unclear if YebC_I is functionally related to $\mathrm{RecU}$. In contrast, there is no evidence that YebC_II subgroup might be involved in RuvABC-dependent Holliday junction resolution, even though only YebC_II members were observed in most Bacteroidetes, Epsilonproteobacteria and Gammaproteobacteria/Vibrionaceae that have RuvABC resolvasome. Thus, it appeared that YebC_I proteins are functionally associated with RuvABC resolution system. YebC_II might have evolved from YebC_I proteins with novel function. It should be noted that several YebC_I proteins were also found in a small number of organisms that lacked the complete RuvABC or RuvAB/RecU system, implying that YebC_I might have additional function in these organisms.

Multiple alignment of YebC_I and YebC_II sequences suggested several specific residues which are only present in each subfamily (Figure 4). An attractive hypothesis is that YebC_I is functionally different from YebC_II, perhaps distinguished by some of these conserved residues. 


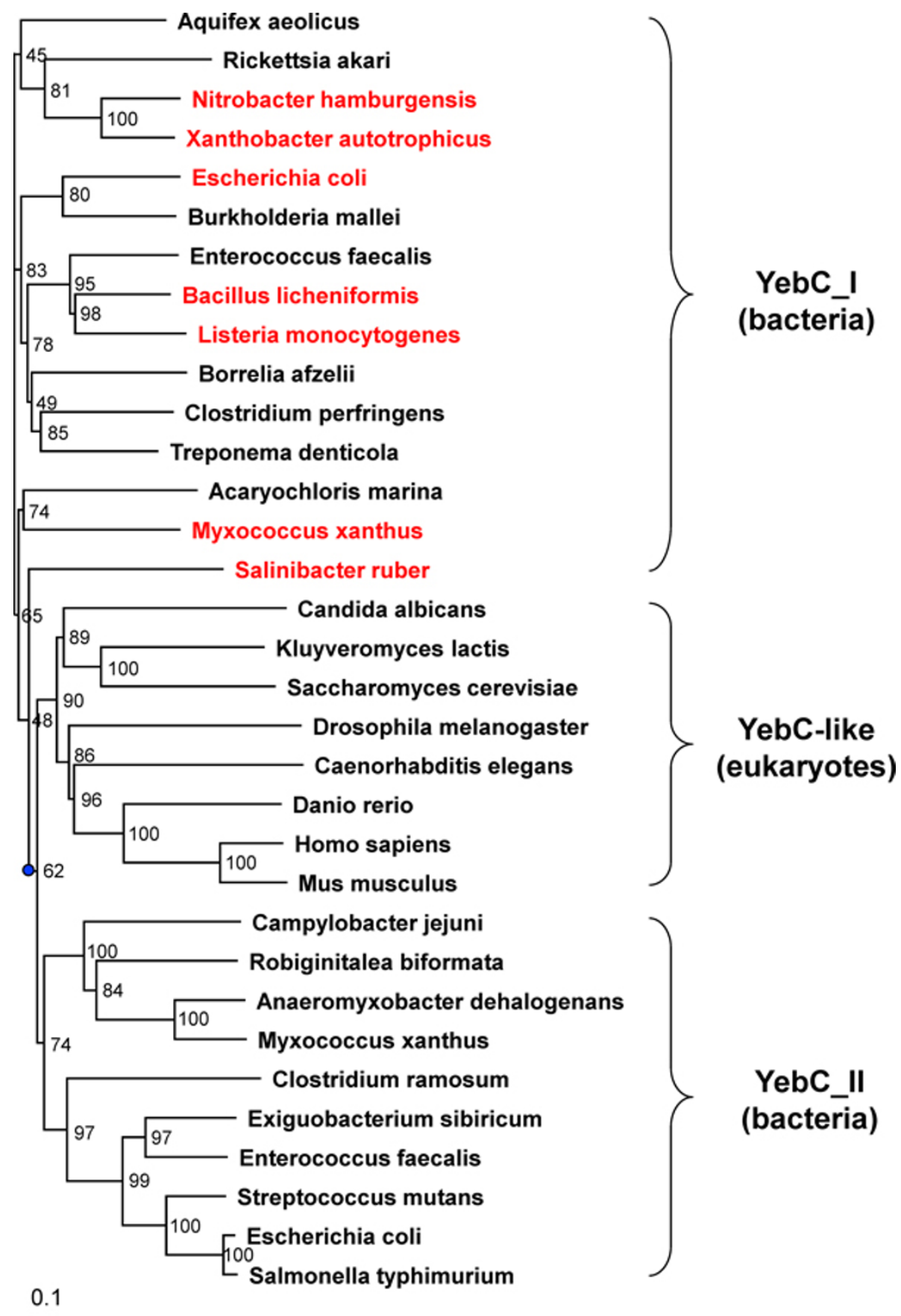

Figure 2 Phylogenetic analysis of YebC family. Organisms where YebC genes are located very close to RuvABC genes are shown in red. The root node of the tree is shown as a blue dot. Separate branches for the two subtypes of YebC in bacteria and the eukaryotic YebC-like proteins are also shown. Both bootstrap support (the number of times each branch was supported in bootstrap replication) and the measurement of distance for the branch lengths (shown by a bar) are indicated.

Prediction of the function of YebC proteins

Although YebC is a large family of widespread conserved proteins whose function is unknown, this group of proteins has been extensively characterized from the structural perspective. To date, the crystal structures of
YebC proteins from Aquifex aeolicus (YebC_I), E. coli (YebC_I), and Helicobacter pylori (YebC_II) have been solved (PDB ID codes $1 \mathrm{LFP}, 1 \mathrm{KON}$, and $1 \mathrm{MW} 7$, respectively). A previous structural analysis of $A$. aeolicus YebC revealed a large cavity with a predominance of 


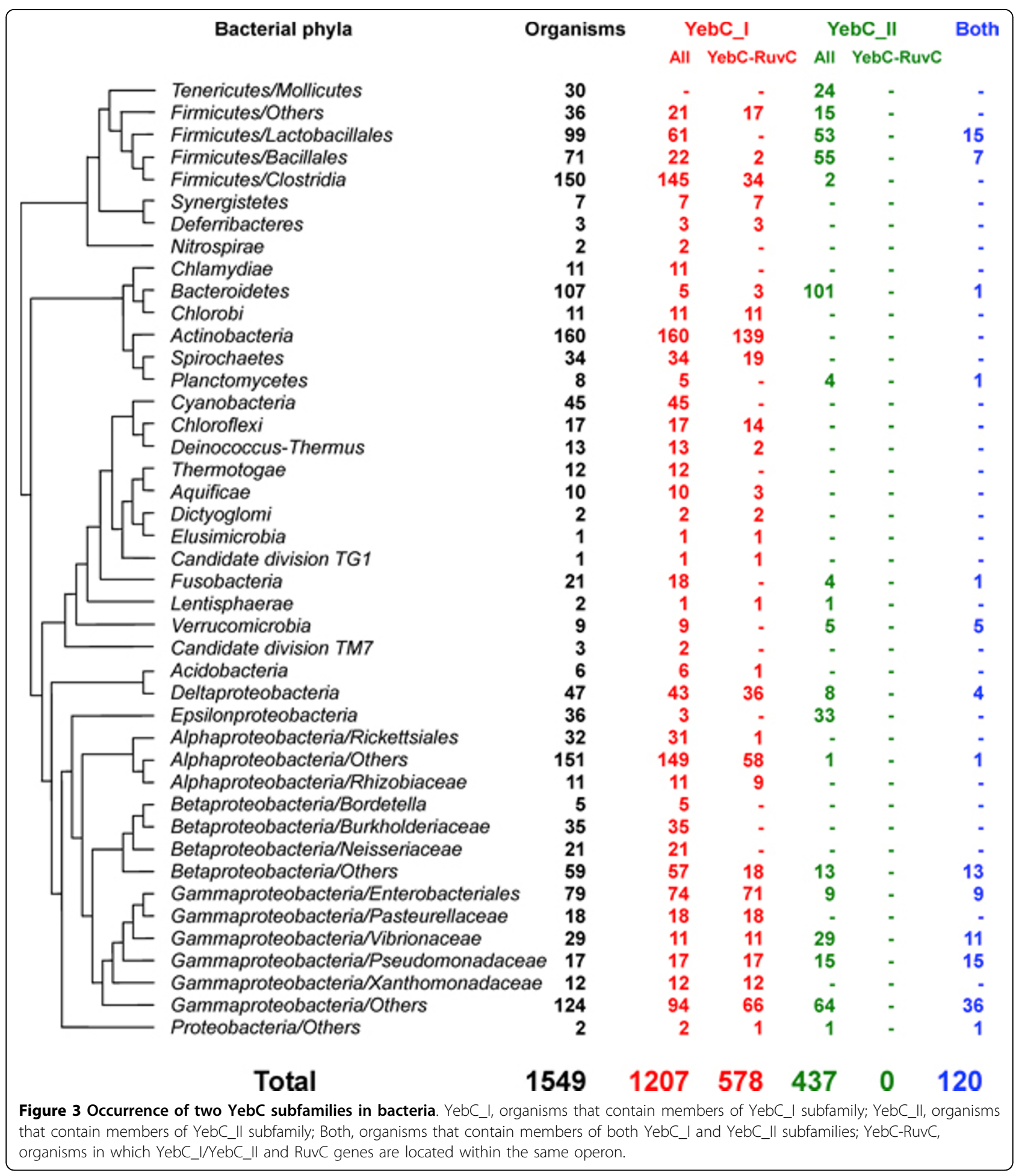

negatively charged residues on the surface of this protein [39]. Interestingly, all three structure-solved proteins have a putative DNA binding function, suggesting that YebC proteins may serve as a potential transcription factor. A recent study reported that the YebC protein in Pseudomonas aeruginosa (PA0964, YebC_I) may be involved in negatively regulating the quorum-sensing response regulator pqsR of the PQS system by binding at its promoter region [40]. This result implied the complexity of the function of $\mathrm{YebC}$ in nature.

Although the function of YebC proteins and the biological pathways they are involved in are unclear, our 

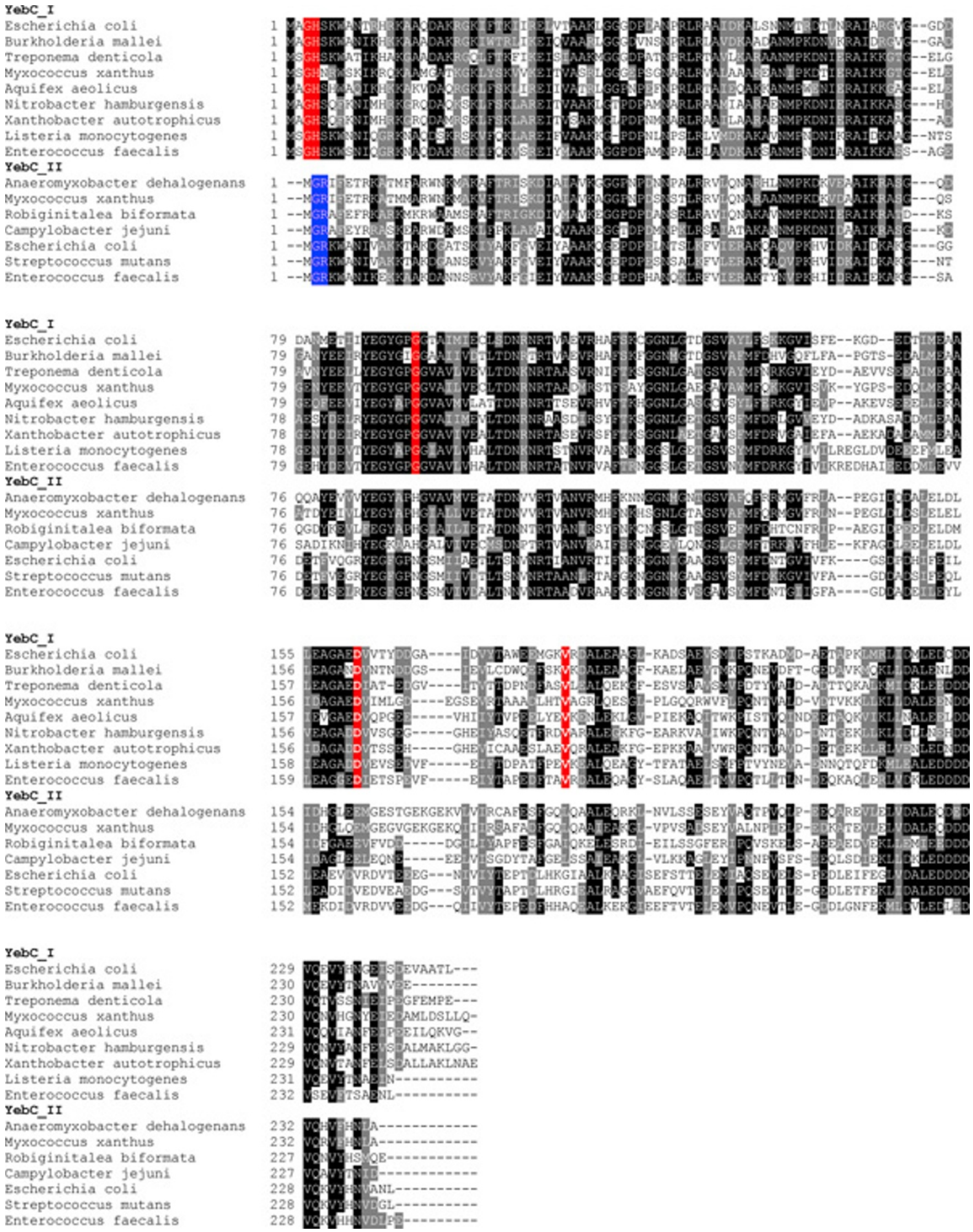

Figure 4 Multiple sequence alignment of YebC proteins in bacteria. Representative sequences were divided into YebC_I and YebC_I subgroups. Residues which are strictly conserved in the YebC_I subgroup are shown in red background. Residues which are strictly conserved in the YebC_Il subgroup are shown in blue. Other residues shown in white on black or grey are conserved in homologs.

current studies provide some useful information for this widely used protein family: (i) both YebC_I and YebC_II subgroups may bind DNA; (ii) YebC_I proteins may serve as a multi-functional transcription regulator mainly involved in regulating the expression of RuvABC genes as well as other genes such as pqsR; (iii) YebC_II 
might have evolved from YebC_I by gene duplication and have novel function independent of Holliday junction resolution or even DNA recombination. A future challenge would be to understand the DNA binding patterns of YebC_I and YebC_II proteins as well as additional processes they may regulate.

\section{Investigation of YebC-like proteins in eukaryotes}

Significant YebC homologs were also detected in a variety of eukaryotes, including fungi, plants and animals (Table S2 [see additional file 2]). Very recently, it was reported that a mutation in the human gene encoding a YebC homolog (named CCDC44, localized to the mitochondria) led to a specific defect in the synthesis of the mitochondrial DNA-encoded cytochrome c oxidase subunit I (COX I) [41]. Thus, the human CCDC44 protein was renamed as TACO1, which may serve as a mammalian mitochondrial translational activator of COX I. Possible mechanisms of TACO1 action to ensure translation of COX 1 were also considered: (i) securing an accurate start of translation; (ii) stabilizing the elongating polypeptide; and (iii) interacting with the peptide release factor $[41,42]$.

We analyzed the sequences of all eukaryotic YebC-like proteins and the evolutionary relationship with their bacterial counterparts. All detected YebC-like proteins in eukaryotes have mitochondrial signal sequences, suggesting that they are mitochondria-targeted proteins. Phylogenetic analysis of bacterial $\mathrm{YebC}$ and eukaryotic YebC-like proteins showed that the eukaryotic YebClike proteins were clustered with YebC_II subfamilies (Figure 2), implying that these YebC-like proteins (including human TACO1) might have evolved from ancient YebC_II proteins. The mitochondrial signal sequences were then added to target them into the mitochondria as a specific translational activator, at least in metazoan mitochondrial genome. As eukaryotes lack the RuvABC resolvasome, it is unclear whether these YebC-like proteins are involved in homologous recombination in mitochondria, or whether they still have the capacity to bind mitochondrial DNA. Further studies are required to determine the substrates and function of YebC-like proteins in other organisms as well as their relationship with DNA repair and recombination in mitochondria.

\section{Prediction of additional phylum-specific genes associated with RuvABC resolvasome}

Comparative genomics studies also suggested additional candidate genes involved in RuvABC-dependent Holliday junction resolution in certain bacterial phyla. In Firmicutes/Clostridia, most organisms possess a conserved hypothetical protein (CTC02214 in Clostridium tetani, a distant homolog of pfam08955, BofC C-terminal domain) whose gene is always located next to either YebC or RuvC gene, implying a potential functional link with them. However, orthologs of this protein family were exclusively detected in Clostridia, suggesting that this protein might be newly evolved in this phylum. Similarly, another conserved hypothetical protein (DUF208 super family; COG1636, uncharacterized protein conserved in bacteria) was also identified in a variety of distantly related organisms where its gene is often located close to either YebC or RuvABC genes (data not shown). Further studies, however, are needed to verify their function and the relationship between these genes and genetic recombination in bacteria.

\section{Conclusions}

In this study, we carried out comparative genomics to identify a novel DNA-binding regulatory protein family, YebC, which was strongly linked to Holliday junction resolution in bacteria. Phylogenetic analysis revealed that YebC might be divided into two functionally different subgroups: YebC_I and YebC_II. YebC_I may serve as a multi-functional transcriptional regulator that mainly regulates the gene expression of RuvABC resolvasome in bacteria. It could not be excluded that YebC_II is involved in homologous recombination, but current evidence does not provide strong support for this possibility. Further studies on eukaryotic YebC-like proteins suggested that they may have evolved from YebC_II subgroup and have different function to serve as a specific translational activator in mitochondria.

\section{Methods}

\section{Genomes, sequences and resources}

Fully sequenced genomes from the Entrez Genome Database at NCBI were used in this study [43]. Because of the large number of strains for some bacterial species, only one strain was selected for each species. A total of 1549 bacteria, 97 archaea and 330 eukaryotes were analyzed (as of October 2011).

We used E. coli RuvA (COG0632, Holliday junction resolvasome DNA-binding subunit), RuvB (COG2255, Holliday junction resolvasome helicase subunit), RuvC (COG0817, Holliday junction resolvasome endonuclease subunit) and Bacillus subtilis RecU (pfam03838, recombination protein $U$ ) sequences as queries to search for RuvABC or RuvAB/RecU-dependent Holliday junction resolution trait. For each of these proteins, TBLASTN [44] was initially used to identify genes coding for homologs with a cutoff of E-value $\leq 0.1$. Orthologous proteins were then defined using the conserved domain (COG/Pfam) database and bidirectional best hits [45].

The STRING (Search Tool for the Retrieval of Interacting Genes/Proteins) database and programs [35] were used to identify gene candidates that may be 
functionally related to RuvABC resolvasome. Different parameters were used for better performance.

\section{Multiple sequence alignment and phylogenetic analysis} Sequence alignments were performed with CLUSTALW [46] using default parameters. Ambiguous alignments in highly variable (gap-rich) regions were excluded. The resulting multiple alignments were then checked for conservation of residues and manually edited. Phylogenetic analyses were performed using PHYLIP programs [47]. Pairwise distance matrices were calculated by PROTDIST to estimate the expected amino acid replacements per position. Neighbor-joining trees were obtained with NEIGHBOR and the most parsimonious trees were determined with PROTPARS.

\section{Additional material}

Additional file 1: This file contains the distribution of RuvA, RuvB, RuvC, RecU and YebC genes in sequenced bacteria

Additional file 2: This file contains the distribution of YebC-like genes in sequenced eukaryotes.

\section{List of abbreviations}

COX I: cytochrome c oxidase subunit I; STRING: Search Tool for the Retrieval of Interacting Genes/Proteins.

\section{Acknowledgements and funding}

We are grateful to Dr. Vadim N. Gladyshev (Division of Genetics, Department of Medicine, Brigham \& Women's Hospital, Harvard Medical School, Boston, MA, USA) for the insightful suggestion and comments. This work was supported by the National Natural Science Foundation of China under NO. 31171233 (Y.Z.).

This article has been published as part of BMC Systems Biology Volume 6 Supplement 1, 2012: Selected articles from The 5th IEEE International Conference on Systems Biology (ISB 2011). The full contents of the supplement are available online at http://www.biomedcentral.com/ bmcsystbiol/supplements/6/S1.

\section{Author details}

${ }^{1}$ Key Laboratory of Systems Biology, Shanghai Institutes for Biological Sciences, Chinese Academy of Sciences, Shanghai, 200031 China. ${ }^{2}$ Computer Network Information Center, Institute of Basic Medical Sciences, Chinese Academy of Medical Sciences and Peking Union Medical College, Beijing, 100005 China.

\section{Authors' contributions}

YZ designed the study. YZ carried out computational studies, including comparative genomics, sequence alignment, phylogenetic analysis and wrote the manuscript. $J L$ and $Y G$ analyzed the data and edited the manuscript. All authors read and approved the final manuscript.

\section{Competing interests}

The authors declare that they have no competing interests.

Published: 16 July 2012

\section{References}

1. Shinohara A, Ogawa T: Homologous recombination and the roles of double-strand breaks. Trends Biochem Sci 1995, 20:387-391.

2. Camerini-Otero RD, Hsieh P: Homologous recombination proteins in prokaryotes and eukaryotes. Annu Rev Genet 1995, 29:509-552.
3. Kuzminov A: DNA replication meets genetic exchange: chromosomal damage and its repair by homologous recombination. Proc Natl Acad Sci USA 2001, 98:8461-8468.

4. Yanowitz J: Meiosis: making a break for it. Curr Opin Cell Biol 2010, 22:744-751.

5. Lawrence JG, Retchless AC: The interplay of homologous recombination and horizontal gene transfer in bacterial speciation. Methods $\mathrm{Mol}$ Biol 2009, 532:29-53.

6. Holliday R: A mechanism for gene conversion in fungi. Genet Res 1964 5:282-304.

7. Constantinou A, Davies AA, West SC: Branch migration and Holliday junction resolution catalyzed by activities from mammalian cells. Cell 2001, 104:259-268.

8. Ho PS, Eichman BF: The crystal structures of DNA Holliday junctions. Curr Opin Struct Biol 2001, 11:302-308.

9. Sharples GJ, Ingleston SM, Lloyd RG: Holliday junction processing in bacteria: insights from the evolutionary conservation of RuvABC, RecG, and RusA. J Bacteriol 1999, 181:5543-5550.

10. White MF: Homologous recombination in the archaea: the means justify the ends. Biochem Soc Trans 2011, 39:15-19.

11. Sharples GJ: The $X$ philes: structure-specific endonucleases that resolve Holliday junctions. Mol Microbiol 2001, 39:823-834.

12. Déclais $A C$, Lilley DM: New insight into the recognition of branched DNA structure by junction-resolving enzymes. Curr Opin Struct Biol 2008, 18:86-95.

13. West SC: Enzymes and molecular mechanisms of genetic recombination. Annu Rev Biochem 1992, 61:603-640.

14. Kowalczykowski SC, Dixon DA, Eggleston AK, Lauder SD, Rehrauer WM: Biochemistry of homologous recombination in Escherichia coli. Microbiol Rev 1994, 58:401-465.

15. West SC: The RuvABC proteins and Holliday junction processing in Escherichia coli. J Bacteriol 1996, 178:1237-1241.

16. Donaldson $J R$, Courcelle $C T$, Courcelle $J$ : RuvABC is required to resolve holliday junctions that accumulate following replication on damaged templates in Escherichia coli. J Biol Chem 2006, 281:28811-28821.

17. Sanchez H, Kidane D, Reed P, Curtis FA, Cozar MC, Graumann PL, Sharples GJ, Alonso JC: The RuvAB branch migration translocase and RecU Holliday junction resolvase are required for double-stranded DNA break repair in Bacillus subtilis. Genetics 2005, 171:873-883.

18. Rocha EP, Cornet E, Michel B: Comparative and evolutionary analysis of the bacterial homologous recombination systems. PLoS Genet 2005, 1:e15.

19. Lloyd RG, Sharples GJ: Dissociation of synthetic Holliday junctions by $E$. coli RecG protein. EMBO J 1993, 12:17-22.

20. McGlynn P, Lloyd RG: Genome stability and the processing of damaged replication forks by RecG. Trends Genet 2002, 18:413-419.

21. Sharples GJ, Chan SN, Mahdi AA, Whitby MC, Lloyd RG: Processing of intermediates in recombination and DNA repair: identification of a new endonuclease that specifically cleaves Holliday junctions. EMBO J 1994, 13:6133-6142.

22. Chan SN, Vincent SD, Lloyd RG: Recognition and manipulation of branched DNA by the RusA Holliday junction resolvase of Escherichia coli. Nucleic Acids Res 1998, 26:1560-1566.

23. Komori K, Sakae S, Shinagawa H, Morikawa K, Ishino Y: A Holliday junction resolvase from Pyrococcus furiosus: functional similarity to Escherichia coli RuvC provides evidence for conserved mechanism of homologous recombination in Bacteria, Eukarya, and Archaea. Proc Natl Acad Sci USA 1999, 96:8873-8878.

24. Daiyasu $\mathrm{H}$, Komori $\mathrm{K}$, Sakae $\mathrm{S}$, Ishino $\mathrm{Y}$, Toh $\mathrm{H}$ : $\mathrm{Hjc}$ resolvase is a distantly related member of the type II restriction endonuclease family. Nucleic Acids Res 2000, 28:4540-4543.

25. Kleff S, Kemper B, Sternglanz R: Identification and characterization of yeast mutants and the gene for a cruciform cutting endonuclease. $E M B O$ J 1992, 11:699-704.

26. White MF, Lilley DM: The resolving enzyme CCE1 of yeast opens the structure of the four-way DNA junction. J Mol Biol 1997, 266:122-134

27. White MF, Lilley DM: Characterization of a Holliday junction-resolving enzyme from Schizosaccharomyces pombe. Mol Cell Biol 1997, 17:6465-6471.

28. Ip SC, Rass U, Blanco MG, Flynn HR, Skehel JM, West SC: Identification of Holliday junction resolvases from humans and yeast. Nature 2008, 456:357-361 
29. Svendsen JM, Harper JW: GEN1/Yen1 and the SLX4 complex: Solutions to the problem of Holliday junction resolution. Genes Dev 2010, 24:521-536.

30. Rass U, Compton SA, Matos J, Singleton MR, Ip SC, Blanco MG, Griffith JD, West SC: Mechanism of Holliday junction resolution by the human GEN1 protein. Genes Dev 2010, 24:1559-1569.

31. Baharoglu Z, Petranovic M, Flores MJ, Michel B: RuvAB is essential for replication forks reversal in certain replication mutants. $E M B O J 2006$, 25:596-604.

32. Bradley AS, Baharoglu Z, Niewiarowski A, Michel B, Tsaneva IR: Formation of a stable RuvA protein double tetramer is required for efficient branch migration in vitro and for replication fork reversal in vivo. $J \mathrm{Bio} / \mathrm{Chem}$ 2011, 286:22372-22383

33. West SC: Processing of recombination intermediates by the RuvABC proteins. Annu Rev Genet 1997, 31:213-244.

34. Ciccarelli FD, Doerks T, von Mering C, Creevey CJ, Snel B, Bork P: Toward automatic reconstruction of a highly resolved tree of life. Science 2006, 311:1283-1287.

35. The STRING web server. [http://string.embl.de/].

36. Zhuang Z, Song F, Martin BM, Dunaway-Mariano D: The YbgC protein encoded by the $y b g C$ gene of the tol-pal gene cluster of Haemophilus influenzae catalyzes acyl-coenzyme A thioester hydrolysis. FEBS Lett 2002, 516:161-163.

37. Sturgis JN: Organisation and evolution of the tol-pal gene cluster. J Mol Microbiol Biotechnol 2001, 3:113-122.

38. Kolker E, Makarova KS, Shabalina S, Picone AF, Purvine S, Holzman T, Cherny T, Armbruster D, Munson RS Jr, Kolesov G, Frishman D, Galperin MY: Identification and functional analysis of 'hypothetical' genes expressed in Haemophilus influenzae. Nucleic Acids Res 2004, 32:2353-2361.

39. Shin DH, Yokota H, Kim R, Kim SH: Crystal structure of conserved hypothetical protein Aq1575 from Aquifex aeolicus. Proc Natl Acad Sci USA 2002, 99:7980-7985.

40. Liang H, Li L, Dong Z, Surette MG, Duan K: The YebC family protein PA0964 negatively regulates the Pseudomonas aeruginosa quinolone signal system and pyocyanin production. J Bacteriol 2008, 190:6217-6227.

41. Weraarpachai W, Antonicka H, Sasarman F, Seeger J, Schrank B, Kolesar JE, Lochmüller H, Chevrette M, Kaufman BA, Horvath R, Shoubridge EA: Mutation in TACO1, encoding a translational activator of COX I, results in cytochrome c oxidase deficiency and late-onset Leigh syndrome. Nat Genet 2009, 41:833-837.

42. Galperin MY, Koonin EV: From complete genome sequence to 'complete' understanding? Trends Biotechnol 2010, 28:398-406.

43. The NCBI Genome Table. [http://www.ncbi.nlm.nih.gov/sutils/genom_table. cgi].

44. Altschul SF, Gish W, Miller W, Myers EW, Lipman DJ: Basic local alignment search tool. J Mol Biol 1990, 215:403-410.

45. Tatusov RL, Galperin MY, Natale DA, Koonin EV: The COG database: a tool for genome-scale analysis of protein functions and evolution. Nucleic Acids Res 2000, 28:33-36.

46. Thompson JD, Higgins DG, Gibson TJ: CLUSTAL W: improving the sensitivity of progressive multiple sequence alignment through sequence weighting, position-specific gap penalties and weight matrix choice. Nucleic Acids Res 1994, 22:4673-4680.

47. Felsenstein J: PHYLIP: Phylogeny Inference Package (Version 3.2). Cladistics 1989, 5:164-166.

doi:10.1186/1752-0509-6-S1-S20

Cite this article as: Zhang et al:: In silico identification of a multifunctional regulatory protein involved in Holliday junction resolution in bacteria. BMC Systems Biology 2012 6(Suppl 1):S20.

\section{Submit your next manuscript to BioMed Central and take full advantage of:}

- Convenient online submission

- Thorough peer review

- No space constraints or color figure charges

- Immediate publication on acceptance

- Inclusion in PubMed, CAS, Scopus and Google Scholar

- Research which is freely available for redistribution

Submit your manuscript at www.biomedcentral.com/submit
Biomed Central 